\title{
Nurses' attitudes and knowledge regarding patient rights: a systematic review
}

\author{
Atitudes e conhecimentos dos enfermeiros em relação aos \\ direitos do paciente: uma revisão sistemática \\ Actitudes y conocimientos de las enfermeras sobre los derechos \\ de los pacientes: una revisión sistemática
}

How to cite this article:

Mpouzika M, Karanikola M, Panayiotou E, Raftopoulos V, Middleton N, Papathanassoglou E. Nurses' attitudes and knowledge regarding patient rights: a systematic review. Rev Esc Enferm USP. 2021;55:e03678. doi: https://doi.org/10.1590/S1980-220X2019037603678

\author{
Meropi Mpouzika ${ }^{1}$ \\ Maria Karanikola ${ }^{1}$ \\ Elena Panayiotou ${ }^{1}$ \\ Vasilios Raftopoulos ${ }^{2}$ \\ Nicos Middleton ${ }^{1}$ \\ Elizabeth Papathanassoglou ${ }^{3}$ \\ ${ }^{1}$ Cyprus University of Technology, \\ Faculty of Health Sciences, Department \\ of Nursing, Limassol, Cyprus. \\ ${ }^{2}$ Hellenic National Public Health \\ Organization, Athens, Greece. \\ ${ }^{3}$ University of Alberta, Faculty of \\ Nursing, Alberta, Canada.
}

\begin{abstract}
Objective: To synthesize current evidence on nurses' attitudes and/or knowledge on the entire spectrum of patient rights. Method: A systematic search of the literature was performed in Web of Science, PubMed, Scopus and CINAHL. Studies were selected according to pre-defined inclusion/exclusion criteria. The Cochrane and PRISMA guidelines, including templates for systematic reviews, were applied. For rigor assessment, the Critical Appraisal Skills Program Qualitative Research Checklist, and the Center for Evidence-Based Management tool were employed. Results: Thirteen studies were included, that exhibited important methodological limitations, such as convenience sampling, mediocre response rates and inadequate instrument validity. Findings indicated: a) low level of awareness regarding patient rights among nurses, b) knowledge discrepancies on specific aspects of patient rights, c) low priority ascribed to a patient's right to access information, and d) insufficient evidence on formal educational sources of knowledge on the topic of patient rights. Conclusion: Narrow geographical localization, heterogeneity and methodological limitations render generalizability of the conclusions difficult. Further research based on robust methodology is proposed.
\end{abstract}

\section{DESCRIPTORS}

Patient Rights; Ethics, Nursing; Health Knowledge, Attitudes, Practice; Professional Practice; Systematic Review.
Corresponding author: Mpouzika DA Meropi

Department of Nursing, Faculty of Health

Sciences, Cyprus University of Technology

15, Vragadinou str., 3041

Limassol, Cyprus

meropi.mpouzika@cut.ac.cy
Received: 12/10/2019

Approved: 08/03/2020 


\section{INTRODUCTION}

Patient rights are directly linked to human rights. The former include the right to life, physical and mental integrity, autonomy, privacy and the right to a dignified treatment by healthcare providers ${ }^{(1)}$. The International Council of Nurses posits that nurses ought to protect patient rights, anywhere and at any time ${ }^{(2)}$. Thus, nurses are typically viewed as those advocating for patient rights ${ }^{(3)}$. However, for nurses to fulfill this role, several preconditions apply, including nurses' knowledge $\mathrm{e}^{(4)}$ and awareness of patient rights. Constructive attitudes, reflecting beliefs and actions, along with the ability to overcome barriers and further negotiate ethically challenging situations, are also crucial ${ }^{(5)}$. Therefore, when addressing patient rights, it is important to view these as a group of provisions that need to be balanced against each other, and potentially against other priorities, or even against limitations of the law.

Exploration of nurses' awareness on patient rights is important in shaping approaches to support nurses' moral behavior at the patients'/families' best interest ${ }^{(6)}$. Although various aspects of patient rights have been extensively addressed in the literature (e.g., the right to informed consent), it is difficult to form a comprehensive and integrative picture on patient rights, especially from the viewpoint of nurses. Studies investigating particular aspects of the patient rights topic do not provide evidence on: which rights receive low priority compared to others; possible inconsistencies between education and clinical practice; or advocating for patient rights ${ }^{(6)}$.

Based on the above, we aimed to systematically review and synthesize current evidence on nurses' knowledge and attitudes regarding the entire spectrum of patient rights. We explored evidence on a) the sources of nurses' knowledge, b) nurses' level of knowledge and associated factors, c) comparative knowledge on specific aspects of patient rights, and d) nurses' attitudes towards patient rights.

\section{METHOD}

\section{TYPE OF STUDY}

The following steps, that comprise the main features of a systematic review, were applied: (a) implementation of concise research questions and description of a replicated methodology, (b) systematic review of studies, selected according to predefined inclusion and exclusion criteria, (c) quality appraisal of the reviewed articles, (d) display of the characteristics and main results of the identified studies in a systematic and critical way.

\section{SeleCtion CRITERIA}

Inclusion criteria were set as follows: a) aim: investigation of nurses'attitudes and/or knowledge, either self-reported or actual (based on the number of correct answers in a patient rights knowledge test), on the entire spectrum of patient rights, irrespective of the methodological approach applied (qualitative, quantitative); b) sample: inclusion of nurses as the main study sample or as a subgroup of healthcare professionals (optionally along with adult patients); and c) form, language, date: full-text published reports from years 1990 to 2019, written in English. The excluded types of papers were: a) literature reviews, meta-analyses, abstracts, reviews, case reports, comments, editorials, letters, nonpeer-reviewed studies (dissertations, conference papers); b) studies surveying healthcare professionals other than nurses; c) studies that did not report on nurses' responses separately; and d) studies addressing a single aspect of patient rights (e.g. only privacy or autonomy), since we exclusively targeted studies that addressed patient rights comprehensively. This last decision was based on our firm belief that the clinicians' approach to patient rights reflects a set of provisions that can almost never be addressed independently from one another; most clinical situations call for a balance between different sets of rights and prioritization of principles. By targeting studies that address the entire spectrum of patient rights, we aimed to identify which rights may receive less attention by clinicians, as well as misconceptions and gaps in educational preparation. This is a difficult task if one looks at the evidence on discrete aspects of the patient rights spectrum. Developing insight into the elusive balances and priorities on the patient rights topic is a precondition for promoting advocacy and ethical decision making in clinicians ${ }^{(7)}$. Furthermore, aiming to increase the generalizability of the present findings to the entire population of healthcare service users, studies involving special patient populations were excluded. Specifically, studies on patients for whom certain legal issues may apply (e.g., psychiatric inpatients, hospitalized prisoners, individuals with substance use disorders) were excluded, since legislation may differ among countries, and studies originating from multiple backgrounds would not be comparable. Moreover, the inclusion of special populations (e.g., psychiatric patients) might raise distinct issues (e.g., compulsory treatment) which would increase the risk for selection bias.

\section{Data collection}

A thorough search of electronic databases (CINAHL, PUBMED, Web of Science and Academic Search Complete) was performed in February 2019, using combinations of the following terms: "nurse" OR "healthcare professionals" OR "healthcare providers" OR "healthcare workers" OR "healthcare personnel" AND "attitudes" OR "knowledge" OR "perceptions" OR "views" OR “opinions" OR “experiences" OR “awareness" AND "patient rights". An advanced librarian undertook the literature search. Databases were firstly searched for prior, relevant systematic reviews or meta-analyses. Reference lists of retrieved articles were hand-searched for relevant studies.

\section{DATA ANALYSIS AND TREATMENT}

The Cochrane guidelines ${ }^{(8)}$ and Prisma reporting template for systematic reviews ${ }^{(9)}$ were followed. Duplicate studies were removed and study titles and abstracts were independently checked by three reviewers to identify eligible studies. Abstracts and/or full texts were then studied by each investigator to define compatibility with selection 
criteria. Data from identified studies were extracted, based on a pre-structured survey form, and were verified by all authors. Ambiguities were resolved through consultation. Extracted information included sample characteristics, study design, data and subgroup analyses, statistical methods and main outcomes. In cases of several respondent groups, data regarding nurses were isolated and extracted.

Based on the selection criteria, 13 studies were included. The study selection process is depicted in Figure 1. The quality of included studies was independently assessed by three researchers (EP, MK, MM) and consensus was reached over common meetings. The quality of identified quantitative studies was assessed with the CEBM tool (Center for Evidence-Based Management) ${ }^{(10)}$. This tool includes 12 questions: (i) Does the study address a clearly focused question / issue? (ii) Is the research method (study design) appropriate for answering the research question? (iii) Is the method of selection of the study subjects clearly described? (iv) Can the way the sample was obtained introduce (selection) bias? (v) Is the sample representative of the population to which the findings will be referred to? (vi) Is the sample size based on pre-study considerations of statistical power? (vii) Has a satisfactory response rate been achieved? (viii) Are the measurement tools likely to be valid and reliable? (ix) Has the statistical significance been assessed? (x) Are confidence intervals given for the main results? (xi) Could there be confounding factors that haven't been accounted for? (xii) Can the results be applied to your organization?

For the assessment of rigor of qualitative studies, the Critical Appraisal Skills Program Qualitative Research Checklist (CASP) ${ }^{(11)}$ was used, which included the following questions: (i) Is there a clear statement of the aims of the research? (ii) Is a qualitative methodology appropriate? (iii) Is the research design appropriate to address the aims of the research? (iv) Is the recruitment strategy appropriate to the aims of the research? (v) Are the data collected in a way relevant to the research question? (vi) Has the relationship between researcher and participants been adequately considered? (vii) Have ethical issues been taken into consideration? (viii) Has data analysis been sufficiently rigorous? (ix) Is there a clear statement of findings? ( $\mathrm{x}$ ) How valuable is the research?

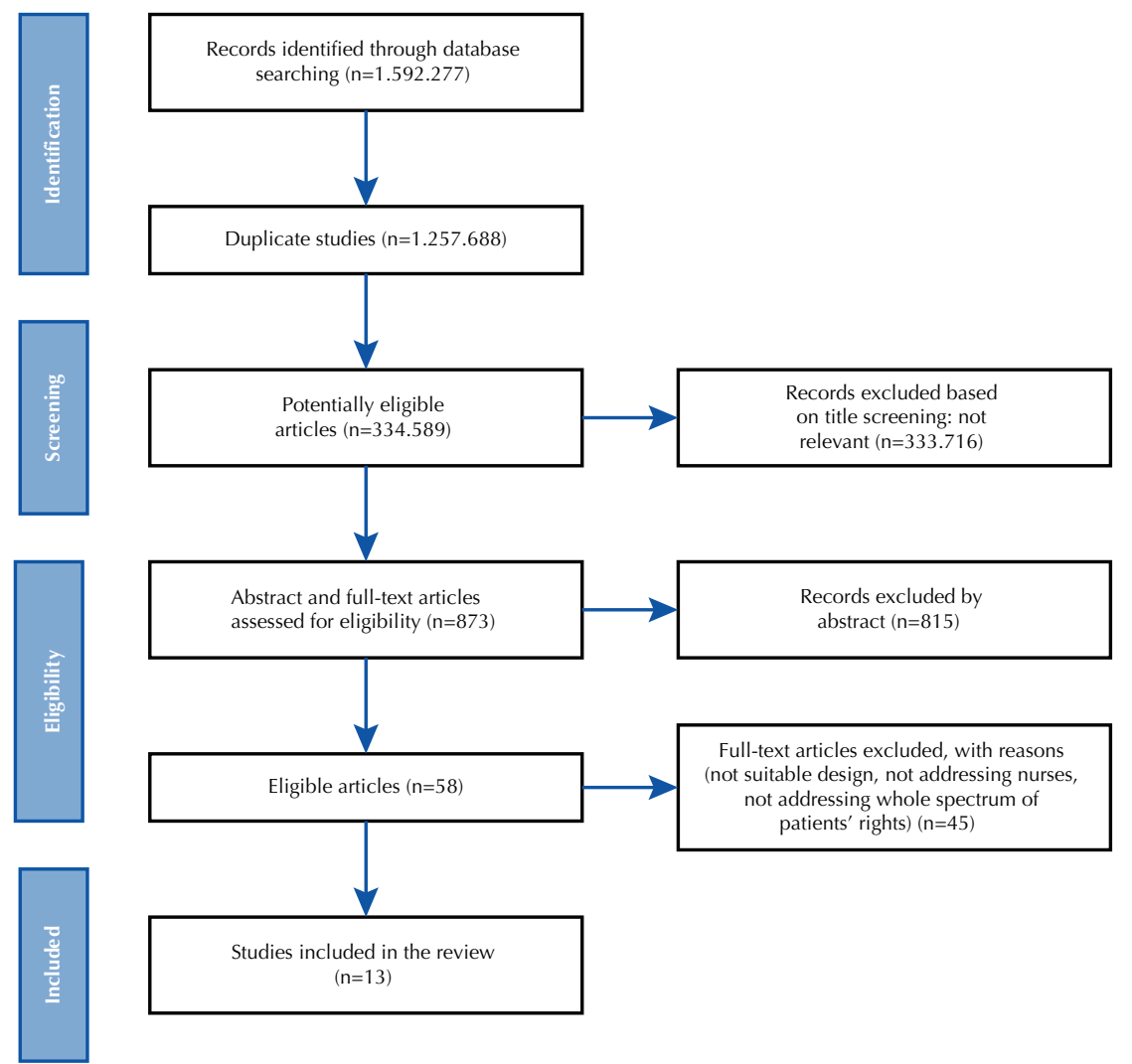

Figure 1 - Flow diagram for identifying and including references in the present systematic review based on PRISMA guidelines strategy ${ }^{(9)}$.

\section{RESULTS}

The included studies are summarized in Chart 1 . We included 13 quantitative studies, conducted in 8 different countries. These studies involved, among other healthcare professionals and patients, 3212 nurses in total, with sample sizes ranging from 80 to 939 . Overall, these studies investigated nurse-reported awareness on the patient rights topic and their views regarding unsatisfied demands of different aspects of patient rights, i.e., patient autonomy, privacy and informed consent. Many data were collected through Likert-type survey questionnaires specifically developed for the purpose of each study. 


\section{QuAlity ASSESSMENT}

Random sampling was employed in two quantitative studies, whereas the rest employed variations of convenience sampling, which may have jeopardized external validity. Apart from six studies with a response rate (RR) between $94.7 \%$ and $100 \%, \mathrm{RR}$ ranged between $50 \%$ and $88 \%$. A low response rate may indicate systematic bias, since nurses who did not consent to participate may have had different views compared to those who participated. Small sample sizes together with convenience sampling may have affected the external validity of reported results. Other limitations stem from novel survey instruments; although in most studies the steps of the instrument development are described, issues of validity remain. Moreover, heterogeneous survey tools render comparisons between studies challenging.

\section{SPECIFIC FINDINGS}

Sources of nurses' knowledge on the patient rights topic. Seven studies addressed nurses' sources of knowledge on patient rights, exhibiting, however, considerable diversity ${ }^{(12-18)}$. The most common sources included undergraduate curricula courses on patient rights, education on nursing ethics, informal experiential learning in the workplace and brochures found in hospitals. In particular, nurses in Egypt identified undergraduate nursing courses, educational programs and sharing experience with colleagues, and to a lesser extent the media or hospital brochures ${ }^{(12-13)}$. Nurses from Turkey reported ethics content to be part of the hospital educational program during nursing orientation training ${ }^{(14)}$. One Iranian study found that nurses with a Master's degree and sufficient work experience seemed to be more aware regarding patient rights $^{(15)}$, while according to a different Iranian survey, one third of participants had not received any relevant education $^{(19)}$. On the contrary, most nurses in Finland $(61 \%)^{(20)}$ reported that they had received formal training related to ethical issues. Nurses in Sudan, Turkey and Barbados reported that hospital training and learning through work were the most prominent sources of knowledge, followed by lectures, seminars and personal study $\mathrm{y}^{(16-18)}$.

Nurses' level of knowledge on patient rights and associated factors. Nurses' level of knowledge on patient rights, either self-reported or actual, was addressed in 12 out of 13 studies $^{(12-23)}$, while the actual level of knowledge was reported in only 2 of these studies ${ }^{(16,20)}$. Despite low self-perceived levels of knowledge in the majority of the samples reviewed herein, when a knowledge test was administered to the Finnish ${ }^{(20)}$ and the Sudanese ${ }^{(16)}$ nurses, a notable discrepancy was seen between actual and self-reported levels, with $68.8 \%$ and $65.8 \%$ of respondents respectively scoring highly on the actual knowledge test. The highest self-reported level of knowledge came from the sample of nurses in Turkey ${ }^{(17)}$. Overall, the relationship of knowledge about patient rights with relevant nursing roles and actual nursing practice may be unclear. In the study involving hospital nurses in Nigeria ${ }^{(21)}$, no relationship was observed between nurses' level of knowledge and advocating for the rights of patients.
Regarding knowledge on relevant legislation, the percentage of participants reporting being aware of the general provisions of the law on patient rights ranged from $50 \%$ to over $90 \%$. Half of the respondents in Egypt ${ }^{(12)}, \operatorname{Sudan}^{(16)}$, Barbados $^{(18)}$ and Finland ${ }^{(20)}$ were not familiar with the content of law on patient rights. Slightly higher self-reported level of knowledge about legislative provisions were observed in the two studies from Iran ( $82 \%$ and $58 \%$, respectively $)^{(15,19)}$.

As for the factors associated with nurses' knowledge about patient rights, the finnish study ${ }^{(20)}$ concluded that older age, advanced years of clinical experience and personal perception about the importance of patient rights were all positively associated with knowledge on patient rights. In two Iranian studies, the level of nurses' knowledge about patient rights was positively related to employment in academic hospitals ${ }^{(22)}$ and the level of education ${ }^{(15)}$, while in a study from Turkey ${ }^{(17)}$ the level of knowledge was related to the nurses' marital status, as well as the circumstances under which the participants firstly heard about patient rights or were faced with a relevant problem.

Comparative knowledge on specific aspects of patient rights. Nurses' knowledge varied across different patient rights and across studies; however, comparisons are challenging due to an observed heterogeneity in measurement tools used for the assessment of nurses' knowledge on patient rights. In Finland ${ }^{(20)}$, the authors assessed nurses' knowledge through a 47-item questionnaire, divided in five topics of patient rights: quality of healthcare treatment and access to it, selfdetermination, access to information, confidentiality, and support of patient ombudsman. The highest knowledge level was observed on issues around quality and access to care, while the lowest regarded patient ombudsman issues. Differences were also noted among different types of nursing personnel, with public sector and bachelor's degree nurses exhibiting slightly higher levels.

In two studies in Iranian nurses, the "right to preserve privacy and confidentiality regarding medical information" received the highest knowledge score, while the patient's right to information about healthcare professionals and cost of care, as well as the right to access personal medical records received the lowest rating ${ }^{(15,19)}$. Similarly, the patient's right to receive information about a healthcare team received the lowest score among Sudanese nurses ${ }^{(16)}$. In a Turkish study, 99.1\% of the responders stated that they safeguard patients' privacy during care and treatment, while $94.3 \%$ were concerned about keeping a patient's secret ${ }^{(14)}$. Equally, in one Egyptian study ${ }^{(13)}$, the "patient's right to receive respectful care" scored the highest, while the "patient's right to refuse prescribed treatment" the lowest.

Nurses' attitudes toward patient rights. Six studies $^{(14,17-18,21,23-24)}$ directly addressed nurses' attitudes towards the topic of patient rights, while the researchers draw in 2 more studies relevant conclusions, although this was not included in the main purpose of these studies ${ }^{(15,22)}$. An Iranian study ${ }^{(24)}$ used a 21-item questionnaire through which nurses' attitudes towards the patient rights to privacy, non-discriminatory treatment and freedom to choose therapy were assessed; the participants put less emphasis on the patient's right to access personal medical records, while emphasized both the 
need for access to an active complaint system, and for disclosure of medical errors. In a survey in Barbados ${ }^{(18)}$, adherence to patient wishes was not viewed as important by $77 \%$ of respondents, while in Nigeria, $91.8 \%$ of the sample agreed that nurses should have an advocacy role ${ }^{(21)}$. In a Turkish study, approximately $98 \%$ of respondents agreed that healthcare services users should be cared for in a safe and friendly environment, with respect and no discrimination ${ }^{(17)}$, while in another Turkish study nurses emphasized positive attitudes towards the patient rights to privacy, confidentiality and informed consent ${ }^{(14)}$. On the contrary, a Korean study on nurses' attitudes towards the patient rights to autonomy, privacy, informed consent and confidentiality revealed that the respondents had poor awareness on these topics ${ }^{(23)}$.

Chart 1 - Summary of included studies.

\begin{tabular}{|c|c|c|c|c|c|c|c|}
\hline $\begin{array}{l}\text { Author(s), } \\
\text { year } \\
\text { (Country) }\end{array}$ & Specific Aims & $\begin{array}{l}\text { Study design } \\
\text { Sampling } \\
\text { Sample RR }\end{array}$ & $\begin{array}{l}\text { Data } \\
\text { collection } \\
\text { tools in } \\
\text { nurses }\end{array}$ & $\begin{array}{c}\text { Results: } \\
\text { Nurses' knowledge } \\
\text { level } \\
\text { (actual/ self-perceived) } \\
\text { \& Associated factors }\end{array}$ & $\begin{array}{c}\text { Results: } \\
\text { Nurses' Attitudes } \\
\text { (beliefs \& clinical } \\
\text { practice) \& } \\
\text { Associated factors }\end{array}$ & $\begin{array}{l}\text {-Sources of } \\
\text { Knowledge } \\
\text {-Formal } \\
\text { education in } \\
\text { the sample } \\
(\%)\end{array}$ & $\begin{array}{l}\text { Quality } \\
\text { appraisal } \\
\text { tool/ Items' } \\
\text { Assessment }\end{array}$ \\
\hline $\begin{array}{l}\text { Hariharan et } \\
\text { al., 2006) }^{(18)} \\
\text { (Barbados) }^{\text {Barbos) }}\end{array}$ & $\begin{array}{c}\text { Exploration } \\
\text { of physicians' } \\
\text { \& nurses' } \\
\text { knowledge, } \\
\text { attitudes } \\
\text { and practice } \\
\text { regarding } \\
\text { healthcare } \\
\text { ethics and law. }\end{array}$ & $\begin{array}{c}\text { Descriptive, } \\
\text { quantitative } \\
\text { study } \\
64 \text { staff nurses, } \\
20 \text { nurses-in- } \\
\text { charge, } \\
27 \text { consultant } \\
\text { physicians \& } \\
48 \text { junior } \\
\text { physicians } \\
\text { RR: not } \\
\text { reported. }\end{array}$ & $\begin{array}{c}\text { Structured } \\
\text { questionnaire }\end{array}$ & $\begin{array}{l}-20 \% \text { reported low } \\
\text { levels of knowledge on } \\
\text { healthcare law system - } \\
37 \% \text { reported lack of } \\
\text { knowledge regarding } \\
\text { the hospital ethics } \\
\text { committee. }\end{array}$ & $\begin{array}{l}-10 \% \text { perceived } \\
\text { knowledge on ethics } \\
\text { as non-important. } \\
\text {-Positive attitudes } \\
\text { were reported on PRs } \\
\text { to confidentiality, } \\
\text { consent for treatment } \\
\text { procedures, freedom } \\
\text { of decision-making, } \\
\text { right to treatment } \\
\text { regardless of patient's } \\
\text { violent behavior } \\
\text {-Negative attitudes } \\
\text { were reported towards } \\
\text { PR to fulfillment of } \\
\text { personal wishes. }\end{array}$ & $\begin{array}{c}\text { Sources: } \\
\text { Pre-graduate } \\
\text { \& orientation } \\
\text { training, } \\
\text { work, } \\
\text { experience, } \\
\text { lectures \& } \\
\text { seminars, } \\
\text { personal study. }\end{array}$ & $\begin{array}{c}\text { CEBM/ } \\
\text { (i), (iii), (vii), } \\
\text { (ix), (xii): yes } \\
\text { (ii), (iv), (v), } \\
\text { (viii): can't tell } \\
\text { (vi), (x), (xi): } \\
\text { no }\end{array}$ \\
\hline $\begin{array}{l}\text { Kim et al., } \\
2008(23) \\
\text { (Korea) }\end{array}$ & $\begin{array}{l}\text { Exploration } \\
\text { of nurses' } \\
\text { awareness } \\
\text { on "Patients' } \\
\text { Bill of Rights" } \\
\text { including the } \\
\text { rights to } \\
\text { autonomy, } \\
\text { informed } \\
\text { consent, } \\
\text { privacy and } \\
\text { confidentiality. }\end{array}$ & $\begin{array}{c}\text { Quantitative, } \\
\text { cross-sectional } \\
\text { design } \\
618 \text { nurses, } \\
\text { RR: } 88.3 \% .\end{array}$ & $\begin{array}{c}\text { Structured } \\
\text { questionnaire }\end{array}$ & $\begin{array}{c}-32.8 \% \text { reported low } \\
\text { levels of knowledge } \\
\text { on the "Patients' Bill of } \\
\text { Rights". }\end{array}$ & $\begin{array}{l}50 \% \text { had violated } \\
\text { patients' privacy \& } \\
\text { confidentiality. }\end{array}$ & Not addressed. & $\begin{array}{c}\text { CEBM/ } \\
\text { (i)-(iii), (vii), } \\
\text { (xii): yes } \\
\text { (iv), (v), (viii): } \\
\text { can't tell } \\
\text { (vi), (ix)-(xi): } \\
\text { no }\end{array}$ \\
\hline $\begin{array}{l}\text { Mohammad } \\
\text { Nejad et al., } \\
2011(19) \\
\text { (Iran) }\end{array}$ & $\begin{array}{l}\text { Evaluation of } \\
\text { knowledge } \\
\text { level in nurses } \\
\text { on PRs and } \\
\text { related factors. }\end{array}$ & $\begin{array}{l}\text { Cross sectional } \\
\text { study } \\
\text { Random } \\
\text { sample } \\
156 \text { nurses, } \\
\text { RR: } 100 \% .\end{array}$ & $\begin{array}{c}\text { Structured } \\
\text { questionnaire }\end{array}$ & $\begin{array}{l}\text {-58.33\% displayed high } \\
\text { knowledge level. } \\
\text {-The highest knowledge } \\
\text { level (95.5\%) was } \\
\text { about PR to privacy \& } \\
\text { confidentiality. - The } \\
\text { lowest knowledge level } \\
(33.9 \% \text { ) was about PRs } \\
\text { to information on the } \\
\text { healthcare team, care } \\
\text { costs and insurance } \\
\text { coverage for other } \\
\text { medical centers. } \\
\text {-Knowledge level was } \\
\text { associated with work } \\
\text { experience ( } \mathrm{p}=0.008) \text {. }\end{array}$ & Not addressed. & $\begin{array}{l}\text { Sources: not } \\
\text { addressed. } \\
\text { 30\%: no } \\
\text { education on } \\
\text { PRs. }\end{array}$ & $\begin{array}{l}\text { CEBM/ } \\
\text { (i)-(iii): can't } \\
\text { tell } \\
\text { (iv)-(vii), (x), } \\
\text { (xi): no } \\
\text { (viii), (ix), (xii): } \\
\text { yes }\end{array}$ \\
\hline $\begin{array}{l}\text { Parsapoor et } \\
\text { al., 2012(24) } \\
\text { (Iran) }\end{array}$ & $\begin{array}{l}\text { Comparison of } \\
\text { the attitudes } \\
\text { of healthcare } \\
\text { service } \\
\text { consumers } \\
\text { and healthcare } \\
\text { providers } \\
\text { regarding PRs. }\end{array}$ & $\begin{array}{c}\text { Descriptive, } \\
\text { cross sectional } \\
\text { design } \\
143 \text { nurses, } \\
\text { RR: } 61 \% . \\
143 \text { patients, } \\
\text { RR: } 98.6 \% .82 \\
\text { physicians, RR: } \\
27.5 \% .\end{array}$ & $\begin{array}{l}\text { Structured, } \\
\text { self- } \\
\text { administered } \\
\text { questionnaire }\end{array}$ & Not addressed & $\begin{array}{c}\text {-Positive attitudes } \\
\text { were reported towards } \\
\text { PRs to confidentiality; } \\
\text { provision of } \\
\text { treatment without } \\
\text { discriminations; } \\
\text { access to information; } \\
\text { freedom of } \\
\text { decision-making on } \\
\text { treatment issues; and } \\
\text { formalsubmission of } \\
\text { complaints. } \\
\text { - Negative attitudes } \\
\text { were reported on } \\
\text { the PR to access } \\
\text { medical records and } \\
\text { information about } \\
\text { medical errors. }\end{array}$ & Not addressed. & $\begin{array}{l}\text { CEBM/ } \\
\text { (i)-(iv), (viii): } \\
\text { can't tell } \\
\text { (v)-(vii), (x), } \\
\text { (xi): no } \\
\text { (ix), (xii): yes }\end{array}$ \\
\hline
\end{tabular}




\begin{tabular}{|c|c|c|c|c|c|c|c|}
\hline $\begin{array}{l}\text { Author(s), } \\
\text { year } \\
\text { (Country) }\end{array}$ & Specific Aims & $\begin{array}{l}\text { Study design } \\
\text { Sampling } \\
\text { Sample RR }\end{array}$ & $\begin{array}{l}\text { Data } \\
\text { collection } \\
\text { tools in } \\
\text { nurses }\end{array}$ & $\begin{array}{c}\text { Results: } \\
\text { Nurses' knowledge } \\
\text { level } \\
\text { (actual/ self-perceived) } \\
\text { \& Associated factors }\end{array}$ & $\begin{array}{c}\text { Results: } \\
\text { Nurses' Attitudes } \\
\text { (beliefs \& clinical } \\
\text { practice) \& } \\
\text { Associated factors }\end{array}$ & $\begin{array}{l}\text {-Sources of } \\
\text { Knowledge } \\
\text {-Formal } \\
\text { education in } \\
\text { the sample } \\
(\%)\end{array}$ & $\begin{array}{c}\text { Quality } \\
\text { appraisal } \\
\text { tool/ Items' } \\
\text { Assessment }\end{array}$ \\
\hline $\begin{array}{l}\text { Iltanen et } \\
\text { al., 2012(20) } \\
\text { (Finland) }\end{array}$ & $\begin{array}{l}\text { Investigation } \\
\text { of knowledge } \\
\text { level and } \\
\text { associated } \\
\text { factors on } \\
\text { PRs among } \\
\text { healthcare } \\
\text { professionals. }\end{array}$ & $\begin{array}{c}\text { Cross sectional } \\
\text { design } \\
\text { Stratified } \\
\text { random } \\
\text { sampling. } \\
191 \text { healthcare } \\
\text { professionals: } \\
52 \text { auxiliary } \\
\text { nurses, } 84 \\
\text { hospital nurses, } \\
37 \text { public } \\
\text { health nurses \& } \\
18 \text { physicians. } \\
\text { Total RR: } 66 \% \text {. }\end{array}$ & $\begin{array}{c}\text { Structured } \\
\text { questionnaire }\end{array}$ & $\begin{array}{l}\text { Close to } 50 \% \text { of } \mathrm{AN} \\
\text { and } \mathrm{HN} \text { and also } 30 \% \\
\text { of PHN had high to } \\
\text { moderate self-evaluated } \\
\text { knowledge level. } \\
\text { Approximately } 90.4 \% \text { of } \\
\text { AN and PHN and } 95 \% \\
\text { of HN reported high self- } \\
\text { evaluated importance } \\
\text { of knowledge on PRs. } \\
\text { Rights with the highest } \\
\text { level of knowledge were } \\
\text { access to decent health } \\
\text { care and treatment } \\
\text { and patient's self- } \\
\text { determination, while } \\
\text { rights with the lowest } \\
\text { level of knowledge were } \\
\text { access to information } \\
\text { and patient ombudsman. }\end{array}$ & Not addressed & $\begin{array}{l}46.2 \% \text { of } \\
\text { AN and RN, } \\
67.1 \% \text { of } \mathrm{HN} \\
\text { and } 62.2 \% \text { of } \\
\text { PHN had no } \\
\text { education on } \\
\text { the PRs topic. }\end{array}$ & $\begin{array}{c}\text { CEBM/ } \\
\text { (i)-(iii), (viii), } \\
\text { (ix), (xi), (xii): } \\
\text { yes } \\
\text { (iv), (v): } \\
\text { Can't tell } \\
\text { (vi), (vii), (x): } \\
\text { no }\end{array}$ \\
\hline $\begin{array}{l}\text { Abou- Zeina } \\
\text { et al., } \\
2013(12) \\
\text { (Egypt) }\end{array}$ & $\begin{array}{l}\text { Assessment } \\
\text { of knowledge } \\
\text { level, relevant } \\
\text { sources } \\
\text { and clinical } \\
\text { practice on } \\
\text { PRs among } \\
\text { healthcare } \\
\text { providers, } \\
\text { patients } \\
\text { and their } \\
\text { companions. }\end{array}$ & $\begin{array}{c}\text { Cross sectional } \\
\text { design } \\
48 \text { nurses, RR: } \\
82.75 \% . \\
72 \text { physicians, } \\
\text { RR: } 81.8 \% . \\
221 \text { patients } \\
\& 71 \\
\text { companions, } \\
\text { RR: } 84.93 \% .\end{array}$ & $\begin{array}{l}\text { Structured, } \\
\text { self- } \\
\text { administered } \\
\text { questionnaire. }\end{array}$ & $\begin{array}{l}48 \% \text { had poor } \\
\text { knowledge. }\end{array}$ & Not addressed. & $\begin{array}{l}\text { Sources: } \\
\text { Undergraduate } \\
\text { curriculum, } \\
\text { colleagues, } \\
\text { media, hospital } \\
\text { brochures. }\end{array}$ & $\begin{array}{c}\text { CEBM/ } \\
\text { (i)-(iii), (vii), } \\
\text { (viii), (xii): yes } \\
\text { (iv), (v): } \\
\text { Can't tell } \\
\text { (vi), (ix)- (xi): } \\
\text { no }\end{array}$ \\
\hline $\begin{array}{l}\text { Akca et al., } \\
2014(17) \\
\text { (Turkey) }\end{array}$ & $\begin{array}{l}\text { Investigation } \\
\text { of nurses' } \\
\text { knowledge } \\
\text { and attitudes } \\
\text { regarding } \\
\text { PRs in order } \\
\text { to design an } \\
\text { educational } \\
\text { program. }\end{array}$ & $\begin{array}{c}\text { Descriptive, } \\
\text { cross-sectional } \\
\text { design } \\
939 \text { nurses, } \\
\text { RR: } 97 \% .\end{array}$ & $\begin{array}{c}\text { Structured, } \\
\text { self- } \\
\text { administered } \\
\text { questionnaire. }\end{array}$ & $\begin{array}{l}\text { Low levels of knowledge } \\
\text { regarding their advocacy } \\
\text { role }(77.8 \%)\end{array}$ & $\begin{array}{l}\text {-Positive attitudes } \\
(<97.1 \%) \text { were } \\
\text { reported about PR } \\
\text { to receive care with } \\
\text { no discriminations, } \\
\text { in a safe, respectful, } \\
\text { attentive and friendly } \\
\text { environment. } \\
\text {-Negative attitudes } \\
(35.8 \%) \text { were reported } \\
\text { towards PR to be } \\
\text { protected by nurses } \\
\text { and be alleviated } \\
\text { from suffering even by } \\
\text { means of euthanasia }\end{array}$ & $\begin{array}{c}\text { Sources: } \\
\text { Hospital } \\
\text { orientation } \\
\text { training } \\
(75.9 \%), \\
\text { pre-graduate } \\
\text { education } \\
(11.2 \%), \text { books, } \\
\text { media (TV), } \\
\text { brochures, } \\
\text { seminars. } \\
92.3 \% \\
\text { had formal } \\
\text { education on } \\
\text { PRs. }\end{array}$ & $\begin{array}{l}\text { CEBM/ } \\
\text { (ii), (iii), (vii), } \\
\text { (ix), (xii): yes } \\
\text { (iv), (v), (viii): } \\
\text { can't tell } \\
\text { (i), (vi), (x), } \\
\text { (xi): no }\end{array}$ \\
\hline $\begin{array}{l}\text { Sabzevari et } \\
\text { al., 2016(22) } \\
\text { (Iran) }\end{array}$ & $\begin{array}{l}\text { Investigation } \\
\text { of PRs } \\
\text { observance } \\
\text { among } \\
\text { healthcare } \\
\text { providers } \\
\text { in teaching } \\
\text { hospitals. }\end{array}$ & 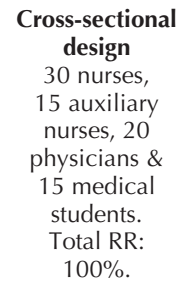 & $\begin{array}{c}\text { Self- } \\
\text { administered } \\
\text { questionnaire } \\
\text { [(demographic } \\
\text { data \& } \\
\text { Inventory } \\
\text { of Patients' } \\
\text { Rights } \\
\text { Observance } \\
\text { (IPRO)]. }\end{array}$ & $\begin{array}{l}\text {-The lowest knowledge } \\
\text { level was reported on } \\
\text { PR to have continuous } \\
\text { access to lawyers } \\
\text { (76.7\%), to participate } \\
\text { in treatment decision- } \\
\text { making }(63.3 \%) \text { and } \\
\text { have access to personal } \\
\text { medical files (50\%). }\end{array}$ & $\begin{array}{c}\text { - Positive attitudes } \\
\text { were reported towards } \\
\text { PRs to participate } \\
\text { in treatment } \\
\text { decisions }(93.3 \%), \\
\text { and to privacy and } \\
\text { confidentiality } \\
(73.3 \%) .\end{array}$ & Not addressed. & $\begin{array}{l}\text { CEBM/ } \\
\text { (i)-(iii), (vii)- } \\
\text { (ix), (xii): yes } \\
\text { (iv), (v): } \\
\text { can't tell } \\
\text { (vi), (x), (xi): } \\
\text { no }\end{array}$ \\
\hline $\begin{array}{l}\text { Sheikhtaheri } \\
\text { et al., } \\
2016(15) \\
\text { (Iran) }\end{array}$ & $\begin{array}{l}\text { Evaluation } \\
\text { of nurses' } \\
\text { knowledge } \\
\text { and adherence } \\
\text { regarding PRs. }\end{array}$ & $\begin{array}{l}\text { Cross-sectional } \\
\text { design } \\
250 \text { nurses, RR: } \\
77.2 \% . \\
300 \text { patients, } \\
\text { RR: } 79.3 \% .\end{array}$ & $\begin{array}{c}\text { Structured, } \\
\text { self- } \\
\text { administered } \\
\text { questionnaire }\end{array}$ & $\begin{array}{l}\text { Factors associated with } \\
\text { higher actual knowledge } \\
\text { level on PRs were } \\
\text { clinical experience } \\
\text { longer than } 10 \text { years and } \\
\text { higher education. }\end{array}$ & $\begin{array}{l}\text {-Acceptable degree of } \\
\text { PRs protection during } \\
\text { everyday clinical } \\
\text { practice } \\
\text {-The least popular } \\
\text { PR was to access to } \\
\text { personal medical } \\
\text { records. }\end{array}$ & $\begin{array}{l}\text { Sources: } \\
\text { Master's } \\
\text { education, } \\
\text { clinical } \\
\text { environment. }\end{array}$ & $\begin{array}{l}\text { CEBM/ } \\
\text { (i)-(iii), (vii)- } \\
\text { (ix), (xii): yes } \\
\text { (iv), (v): } \\
\text { can't tell } \\
\text { (vi), (x), (xi): } \\
\text { no }\end{array}$ \\
\hline $\begin{array}{l}\text { Utkualp et } \\
\text { al., 2016(14) } \\
\text { (Turkey) }\end{array}$ & $\begin{array}{l}\text { Evaluation } \\
\text { of nurses' } \\
\text { knowledge } \\
\text { and attitudes } \\
\text { regrading PRs. }\end{array}$ & $\begin{array}{l}\begin{array}{c}\text { Quantitative, } \\
\text { descriptive } \\
\text { design }\end{array} \\
211 \text { nurses, RR: } \\
56.8 \% .\end{array}$ & $\begin{array}{c}\text { Structured } \\
\text { questionnaire }\end{array}$ & $\begin{array}{c}-79.1 \% \text { reported } \\
\text { adequate knowledge } \\
\text { on PRs. }\end{array}$ & $\begin{array}{c}\text { - Positive attitudes } \\
\text { were reported towards } \\
\text { PR to privacy (99.1\%), } \\
\text { confidentiality } \\
(94.3 \%) \text { and informed } \\
\text { consent }(82.5 \%) .\end{array}$ & $\begin{array}{l}\text { Sources: } \\
\text { Pre-graduate } \\
\text { education, } \\
\text { hospital } \\
\text { orientation } \\
\text { program. }\end{array}$ & $\begin{array}{c}\text { CEBM/ } \\
\text { (i), (ii), (vii), } \\
\text { (ix), (xii): yes } \\
\text { (iii)-(v), (viii): } \\
\text { can't tell } \\
\text { (vi), (x), (xi): } \\
\text { no }\end{array}$ \\
\hline
\end{tabular}

continue... 


\begin{tabular}{|c|c|c|c|c|c|c|c|}
\hline $\begin{array}{l}\text { Author(s), } \\
\text { year } \\
\text { (Country) }\end{array}$ & Specific Aims & $\begin{array}{l}\text { Study design } \\
\text { Sampling } \\
\text { Sample RR }\end{array}$ & $\begin{array}{l}\text { Data } \\
\text { collection } \\
\text { tools in } \\
\text { nurses }\end{array}$ & $\begin{array}{c}\text { Results: } \\
\text { Nurses' knowledge } \\
\text { level } \\
\text { (actual/ self-perceived) } \\
\text { \& Associated factors }\end{array}$ & $\begin{array}{c}\text { Results: } \\
\text { Nurses' Attitudes } \\
\text { (beliefs \& clinical } \\
\text { practice) \& } \\
\text { Associated factors }\end{array}$ & $\begin{array}{l}\text {-Sources of } \\
\text { Knowledge } \\
\text {-Formal } \\
\text { education in } \\
\text { the sample } \\
(\%)\end{array}$ & $\begin{array}{c}\text { Quality } \\
\text { appraisal } \\
\text { tool/ Items' } \\
\text { Assessment }\end{array}$ \\
\hline $\begin{array}{l}\text { Ibrahim et } \\
\text { al., 2017(13) } \\
\text { (Eqypt) }\end{array}$ & $\begin{array}{l}\text { Assessment } \\
\text { of the effect } \\
\text { of a training } \\
\text { program } \\
\text { on nurses' } \\
\& \text { patients' } \\
\text { perceptions } \\
\text { regarding PRs. }\end{array}$ & $\begin{array}{c}\text { Quasi- } \\
\text { Experimental } \\
\text { study } \\
\text { Random } \\
\text { sample. } 97 \\
\text { nurses, RR: } \\
100 \% . \\
135 \text { patients, } \\
\text { RR: } 100 \% .\end{array}$ & $\begin{array}{l}\text { Self- } \\
\text { administered } \\
\text { structured } \\
\text { questionnaire }\end{array}$ & $\begin{array}{l}41.8 \% \text { in governmental } \\
\text { hospitals and } 38.1 \% \text { in } \\
\text { private hospitals had } \\
\text { incorrect or incomplete } \\
\text { knowledge regarding } \\
\text { PRs. }\end{array}$ & Not addressed. & $\begin{array}{l}\text { Sources: } \\
\text { Nursing school } \\
\text { curricula, } \\
\text { training } \\
\text { courses. }\end{array}$ & $\begin{array}{c}\text { CEBM/ } \\
\text { (i), (ii), (vii)- } \\
\text { (ix), (xii): yes } \\
\text { (iii)-(v): } \\
\text { can't tell } \\
\text { (vi), (x), (xi): } \\
\text { no }\end{array}$ \\
\hline $\begin{array}{l}\text { Kolawole, } \\
2017(21) \\
\text { (Nigeria) }\end{array}$ & $\begin{array}{l}\text { Assessment } \\
\text { of nurses' } \\
\text { and patients' } \\
\text { perceptions } \\
\text { regarding } \\
\text { nurses' } \\
\text { advocacy } \\
\text { roles, with } \\
\text { focus on } \\
\text { promoting } \\
\text { safety and } \\
\text { rights of } \\
\text { surgical } \\
\text { patients. }\end{array}$ & $\begin{array}{c}\text { Quantitative, } \\
\text { descriptive } \\
\text { study } \\
\text { Random } \\
\text { sample. } 219 \\
\text { nurses, RR: } \\
100 \% . \\
25 \text { surgical } \\
\text { patients, } \\
\text { RR: } 100 \% .\end{array}$ & $\begin{array}{l}\text { Structured, } \\
\text { self- } \\
\text { administered } \\
\text { questionnaire }\end{array}$ & $\begin{array}{l}89.8 \% \text { had adequate } \\
\text { knowledge about } \\
\text { their advocacy role in } \\
\text { promoting PRs. }\end{array}$ & $\begin{array}{l}-91.8 \% \text { reported } \\
\text { positive attitudes } \\
\text { towards advocacy in } \\
\text { favour of patients } \\
\text { - No relationship was } \\
\text { found between nurses' } \\
\text { knowledge level and } \\
\text { guarding PRs. }\end{array}$ & Not addressed. & $\begin{array}{c}\text { CEBM/ } \\
\text { (i), (ii), (vii)- } \\
\text { (ix), (xii): yes } \\
\text { (iii)-(v): } \\
\text { can't tell } \\
\text { (vi), (x), (xi): } \\
\text { no }\end{array}$ \\
\hline $\begin{array}{l}\text { Abdalla et } \\
\text { al., 2018(16) } \\
\text { (Sudan) }\end{array}$ & $\begin{array}{l}\text { Assessment } \\
\text { of nurses' } \\
\text { knowledge } \\
\text { level regarding } \\
\text { PRs. }\end{array}$ & $\begin{array}{c}\text { Descriptive, } \\
\text { cross-sectional } \\
\text { design } \\
90 \text { nurses, RR: } \\
94.7 \% .\end{array}$ & $\begin{array}{l}\text { Structured, } \\
\text { self- } \\
\text { administered } \\
\text { questionnaire }\end{array}$ & $\begin{array}{l}65.8 \% \text { had an } \\
\text { acceptable level of } \\
\text { knowledge. }\end{array}$ & Not addressed. & $\begin{array}{l}\text { Sources: } \\
\text { Workplace, } \\
\text { pre-graduate } \\
\text { training, media }\end{array}$ & $\begin{array}{c}\text { CEBM/ } \\
\text { (i)-(iii), (vii), } \\
\text { (ix), (xii): yes } \\
\text { (iv), (v), (viii): } \\
\text { can't tell } \\
\text { (vi), (x), (xi): } \\
\text { no }\end{array}$ \\
\hline
\end{tabular}

[RR: Response rate; PR: Patient Right; PRs: Patient Rights; CEBM: Center for Evidence-Based Management; Auxiliary nurses (AN); Hospital nurses (HN); Public health nurses $(\mathrm{PHN})]$.

\section{DISCUSSION}

The present review demonstrated data that support: a) a low level of knowledge regarding patient rights among nurses, b) insufficient evidence regarding sources of knowledge on patient rights for nurses, c) insufficient data on nurses' attitudes towards patient rights, d) discrepancies regarding knowledge on specific aspects of patient rights, both across and within groups of respondents from different countries, and, finally, e) a low prioritization by nurses of the patients' right to access information about the care they receive. Moreover, a lack of methodologically robust studies addressing nurses' knowledge and attitudes towards the entire spectrum of patient rights was identified.

These results need to be considered in view of significant limitations related to the studies from which they stem. Convenience sampling within the research settings and mediocre response rates are significant shortcomings of the included studies. Additionally, assessment tools were often used for the first time with undefined validity, as implied by the notable discrepancy between actual and self-reported levels of knowledge. Moreover, interpretation and synthesis of results is hindered by the great heterogeneity in assessment tools and study populations. The scant representation of European and North American nursing populations is also remarkable. The geographical localization of studies in eastern Mediterranean countries precludes more broad conclusions. Additionally, evidence on the difference in knowledge and attitudes among nurses in diverse healthcare settings is missing.

The limitations of the present review process must also be considered. We confined our search to databases that were more likely to render biomedical studies rather than philosophical literature. This decision was made in order to target nursing personnel. Still, we do not deem this as an important source of bias, in as much as checking for cross-references either electronically or by hand did not yield studies indexed in other databases.

The small number of studies addressing nurses' knowledge and/or attitudes towards patient rights is remarkable, especially in view of evidence on multiple ethical dilemmas among nurses ${ }^{(12,19)}$. One reason could be that nurses may consider that they fulfill their moral obligations by abiding by the codes of ethics of the nursing profession ${ }^{(25)}$. Codes of ethics do encompass patient rights issues, albeit not in detail, and receive high priority among regulatory and professional bodies $^{(26)}$. An additional reason could be the "non-visible" nature of patient rights, which may be viewed as a counterincentive towards conducting relevant studies ${ }^{(27)}$.

The overall level of knowledge regarding patient rights was found to be low, despite the fact that human rights and protection of the public both receive high priority in the nursing codes of ethics ${ }^{(2)}$. Given the role of nurses as patient advocates and educators, low level of knowledge on patient rights among them may also be associated with low patient rights awareness among patients themselves ${ }^{(6)}$. Nonetheless, a 
high level of knowledge does not guarantee implementation in practice, as several barriers may exist, including coercion and conflicts of interest ${ }^{(21)}$.

The present review suggests potential deficiencies of preand post-registration education on nursing ethics. Gaps in nurses' knowledge may be related to outdated and rigid sources of knowledge, as well. Our results indicate undergraduate curricula as the prevailing source of knowledge on patient rights across countries. However, gaps in undergraduate nursing education regarding ethics and patient rights have been consistently reported in the literature ${ }^{(22,28)}$. Moreover, disillusionment and encountering ethical misconduct during undergraduate nursing education have been identified as barriers to the development of moral agency in nursing students. Providing opportunities for ethical reflection, rather than lecture-based training alone, has been suggested as a powerful means of instituting ethical principles ${ }^{(3)}$.

It is noteworthy that brochures and print-outs on patient rights issues were not reported frequently among main sources of knowledge. Therefore, it appears that the popular practice of posting a bill of patient rights in hospital wards can only have a minimal impact on raising awareness among health professionals. Additionally, alternative sources of knowledge, such as colleagues and peer communities, need to be purposefully addressed to increase insight on patient rights.

Although discrepancies in the type and scope of assessment tools render comparisons of knowledge levels on specific patient rights challenging, the results also raise the possibility of discrepancies between actual and self-reported levels of knowledge, with a potential underestimation of real knowledge. This needs to be taken into account in future research. On the other hand, the often-commonsensical content of several provisions of patient rights might also account for deceptively high scores in knowledge tests, even among nurses who report being unaware of the law. While intuition may inform many of the ethical decisions that nurses make ${ }^{(25)}$, it may also bear pitfalls inasmuch as clinicians may base their judgments on misperceptions rather than on actual knowledge of legislative provisions. The identified studies regarding exploration of factors related to nurses' knowledge on patient rights are limited. However, attitudes appear to be associated with the degree of knowledge ${ }^{(29)}$. Nurses' knowledge and attitudes towards specific articles of patient rights may be associated with the type of unit nurses are employed in, since different ethical issues arise at different clinical settings ${ }^{(7)}$. This may account for variance in nurses' awareness due to differential exposure to ethical issues. Although the findings of the Finnish study suggest slightly higher knowledge levels among public sector nurses ${ }^{(20)}$, overall, data are limited in this respect. Therefore, the clinical setting could be an important determinant of awareness on patient rights.

This review suggests that nurses may be more aware of aspects of the law regarding issues of care quality and access to care, and less aware about patients' freedom of choice. It is worth exploring whether such "partialities" may be associated with inherent priorities dictated by the healthcare system and patients themselves. Although no firm conclusions can be drawn due to data heterogeneity, this review suggests that the patient rights to information and freedom of choice may be jeopardized. This issue is intricately involved in the patient's right to autonomy, which has been suggested as being problematic in previous studies ${ }^{(30)}$.

\section{CONCLUSION}

The scarcity of relevant literature, the narrow geographical localization of identified studies, as well as study heterogeneity and methodological limitations render generalizability of conclusions difficult. The results suggest low levels of awareness regarding patient rights among hospital nurses and discrepancies regarding knowledge and attitudes towards specific rights, both across and within groups of respondents from different countries. Moreover, the results highlight deficiencies of pre- and post-registration education on nursing ethics and identify potential factors associated with nurses' knowledge level, such as positive attitudes and more years of nursing experience. The relationship between knowledge on patient rights and implementation of those rights in everyday practice, as well as the existence of potential barriers to implementation, have not been adequately addressed to date and merit investigation.

\section{RESUMO}

Objetivo: Sintetizar as evidências atuais sobre as atitudes e/ou conhecimentos dos enfermeiros sobre todo o espectro dos direitos do paciente. Método: Uma busca sistemática da literatura foi realizada na Web of Science, PubMed, Scopus e CINAHL. Os estudos foram selecionados de acordo com critérios de inclusão/exclusão pré-definidos. As diretrizes Cochrane e PRISMA, incluindo modelos para revisões sistemáticas, foram aplicadas. Para uma avaliação rigorosa, foram utilizados o Critical Appraisal Skills Program Qualitative Research Checklist e a ferramenta do Center for Evidence-Based Management. Resultados: Foram incluídos 13 estudos que exibiram limitações metodológicas importantes, como amostragem por conveniência, taxas de resposta medíocres e validade inadequada do instrumento. Os resultados indicaram: a) baixo nível de consciência sobre os direitos do paciente entre os enfermeiros, b) discrepâncias de conhecimento sobre aspectos específicos dos direitos do paciente, c) baixa prioridade atribuída ao direito do paciente de acessar informações, e d) evidências insuficientes sobre fontes de conhecimento educacionais formais sobre o tema dos direitos do paciente. Conclusão: A localização geográfica estreita, a heterogeneidade e as limitações metodológicas dificultam a generalização das conclusões. Outras pesquisas baseadas em metodologia robusta são propostas.

\section{DESCRITORES}

Direitos do Paciente; Ética em Enfermagem; Conhecimentos, Atitudes e Práticas em Saúde; Prática Profissional; Revisão Sistemática.

\section{RESUMEN}

Objetivo: Sintetizar la evidencia actual sobre las actitudes y/o conocimientos de las enfermeras sobre todo el espectro de los derechos del paciente. Método: Se realizó una búsqueda sistemática de la literatura en Web of Science, PubMed, Scopus y CINAHL. Los estudios se seleccionaron de acuerdo con criterios de inclusión/exclusión predefinidos. Se aplicaron las guías Cochrane y PRISMA, incluidas las 
plantillas para revisiones sistemáticas. Para una evaluación más rigurosa, se emplearon el Critical Appraisal Skills Program Qualitative Research Checklist y la herramienta del Center for Evidence-Based Management. Resultados: Se incluyeron trece estudios, que exhibieron importantes limitaciones metodológicas, como muestreo por conveniencia, tasas de respuesta mediocres y validez inadecuada del instrumento. Los hallazgos indicaron: a) bajo nivel de conciencia sobre los derechos del paciente entre las enfermeras, b) discrepancias de conocimiento sobre aspectos específicos de los derechos del paciente, c) baja prioridad atribuida al derecho del paciente a acceder a la información, y d) evidencia insuficiente sobre fuentes formales de conocimiento educativo sobre el tema de los derechos del paciente. Conclusión: La estrecha localización geográfica, la heterogeneidad y las limitaciones metodológicas dificultan la generalización de las conclusiones. Se propone más investigación basada en una metodología robusta.

\section{DESCRIPTORES}

Derechos del Paciente; Ética en Enfermería; Conocimientos, Actitudes y Práctica en Salud; Práctica Profesional; Revisión Sistemática.

\section{REFERENCES}

1. United Nations; International Institute for Democracy and Electoral Assistance. Democracy and human rights: the role of the UN [Internet]. New York: UN/International IDEA; 2013 [cited 2019 May 12]. Available from: https://www.idea.int/publications/catalogue/democracyand-human-rights-role-united-nations?lang=en

2. International Council of Nurses. The ICN Code of Ethics for Nurses: revised 2012. [Internet] Geneva: ICN; 2012 [cited 2019 May 12]. Available from: https://www.icn.ch/sites/default/files/inlinefiles/2012_ICN_Codeofethicsfornurses_\%20eng.pdf

3. Davoodvand S, Abbaszadeh A, Ahmadi F. Patient advocacy from the clinical nurses' viewpoint: a qualitative study. J Med Ethics Hist Med [Internet]. 2016[cited 2019 May 12];9:5. Available from: https://www.ncbi.nlm.nih.gov/pmc/articles/PMC4958925/

4. Heidari A, Ahmadpour Z, GharehBoughlou Z. Patients' and nurses' awareness of patients' rights: a comparative study. Health Spiritual Med Ethics [Internet]. 2014 [cited 2019 May 12];1(1):2-8. Available from: http://jhsme.muq.ac.ir/content/18/About-the-journal

5. Turale S. Ethical dilemmas: the challenge of advocating for human rights. Int Nurs Rev. 2014;61(3):299-300. doi: 10.1111/inr.12130

6. Abedi G, Shojaee J, Moosazadeh M, Rostami F, Nadi A, Abedini E, et al. Awareness and observance of patient rights from the perspective of Iranian patients: a systematic review and meta-analysis. Iran J Med Sci [Internet]. 2017 [cited 2019 May 12];42(3):227-34. Available from: https://www.ncbi.nlm.nih.gov/pmc/articles/PMC5429490/

7. Park M, Jeon SH, Hong HJ, Cho SH. A comparison of ethical issues in nursing practice across nursing units. Nurs Ethics. 2014;21(5):594607. doi: $10.1177 / 0969733013513212$

8. Higgins JPT, Thomas J, Chandler J, Cumpston M, Li T, Page MJ, et al, editors. Cochrane Handbook for Systematic Reviews of Interventions version 6.0 [Internet]. Cochrane; 2019 [cited 2019 Feb 21]. Available from: www.training.cochrane.org/handbook

9. Moher D, Liberati A, Tetzlaff J, Altman DG, PRISMA Group. Preferred reporting items for systematic reviews and meta-analyses: the PRISMA statement. PLoS Med. 2009;6(7): e1000097. doi: 10.1371/journal.pmed.1000097

10. Center for Evidence-Based Management. Critical appraisal of a survey [Internet]. Oxford: CEBM; 1996 [cited 2019 Feb 21]. Available from: https://www.cebma.org/wp-content/uploads/Critical-Appraisal-Questions-for-a-Survey.pdf

11. Critical Appraisal Skills Program. CASP checklists [Internet]. Oxford: CASP; 2018 [cited 2019 Feb 21]. Available from: https://casp-uk. net/casp-tools-checklists/

12. Abou-Zeina HA, Nouman AA, Zayed MA, Hifnawy T, Shabrawy EM, Tahlawy E. Patients' rights: a hospital survey in South Egypt. J Empir Res Hum Res Ethics. 2013;8(3):46-52. doi: 10.1525/jer.2013.8.3.46

13. Ibrahim SA, Hassan MA, Hamouda SI, Abd Allah NM. Effect of patients' rights training sessions for nurses and patients. Nurs Ethics. 2017;24(7):856-67. doi: 10.1177/0969733015625365

14. Utkualp N, Yildiz H. Awareness and attıtudes of nurses workıng in a unıversıty hospıtal on patıents' rıghts. Int J Car Sci. 2016;9(1):185-97. Available from: http://www.internationaljournalofcaringsciences.org/

15. Sheikhtaheri A, Jabali MS, Dehaghi ZH. Nurses' knowledge and performance of the patients' bill of rights. Nurs Ethics. 2016;23(8):866-76. doi: 10.1177/0969733015584967

16. Abdalla SM, Mahgoub EA, Abdelgadir J, Elhassan N, Omer Z. Operationalization of patients' rights in Sudan: quantifying nurses' knowledge. Nurs Ethics. 2018;26(7-8):2239-46. doi: 10.1177/0969733018787224

17. Akca SO, Akpinar YY, Habbani T. Knowledge and attitudes of nurses regarding patient rights: a Corum/Turkey sample. Rev Assoc Med Bras. 2015;61(5):452-57. doi: 10.1590/1806-9282.61.05.452

18. Hariharan S, Jonnalagadda R, Walrond E, Moseley H. Knowledge, attitudes and practice of healthcare ethics and law among doctors and nurses in Barbados. BMC Med Ethics. 2006;9:7:E7. doi: 10.1186/1472-6939-7-7

19. Mohammad Nejad E, Begjani J, Abotalebi G, Salari A, Ehsani SR. Nurses awareness of patients rights in a teaching hospital. J Med Ethics Hist Med [Internet]. 2011 [cited 2019 Feb 21];4(2):1-6. Available from: http://jmehm.tums.ac.ir/index.php/jmehm

20. Iltanen S, Leino-Kilpi H, Puukka P, Suhonen R. Knowledge about patients' rights among professionals in public health care in Finland. Scand J Caring Sci.2012;26(3):436-48. doi: 10.1111/j.1471-6712.2011.00945.x

21. Kolawole IO. Nurses' perception and patients' validation of nurses' advocacy roles in promotion of surgical patients' safety and rights in three hospitals, Ibadan, Nigeria. West African J Nurs [Internet]. 2017 [cited 2019 Feb 21];28(1):66-84. Available from: https://www. worldcat.org/title/west-african-journal-of-nursing/oclc/70052832

22. Sabzevari A, Kiani MA, Saeidi M, Jafari SA, Kianifar H., Ahanchian H, et al. Evaluation of patients' rights observance according to patients' rights charter in educational hospitals affiliated to Mashhad University of medical sciences: medical staffs' views. Electron Physician. 2016;8(10):3102-09. doi: 10.19082/3102

23. Kim YS, Yoo MS, Park JH. Korean nurses' awareness of patients' rights in hospitals. Korean J Med Ethics Educ. 2008;11(2):191-200. doi: 10.35301/ksme.2008.11.2.191 
24. Parsapoor A, Mohammad K, Malek Afzali H, Ala'eddini F, Larijani B. Necessity of observing patient's rights: a survey on the attitudes of patients, nurses and physicians. J Med Ethics Hist Med [Internet]. 2012 [cited 2019 Feb 21];5(2):1-9. Available from: http://jmehm.tums. ac.ir/index.php/jmehm

25. Alba B. Factors that impact on emergency nurses' ethical decision-making ability. Nurs Ethics. 2016;25(7):855-66. doi: $10.1177 / 0969733016674769$

26. Tarzian AJ, Wocial LD; ASBH Clinical Ethics Consultation Affairs Committee. A code of ethics for health care ethics consultants: journey to the present and implications for the field. Am J Bioeth. 2015;15(5):38-51. doi: 10.1080/15265161.2015.1021966.

27. Yarney L, Buabeng T, Baidoo D, Bawole JN. Operationalization of the Ghanaian patients' Charter in a peri-urban public hospital: voices of healthcare workers and patients. Int J Health Policy Manag. 2016;5(9):525-33. doi: 10.15171/ijhpm.2016.42

28. Chao SY, Chang YC, Yang SC, Clark MJ. Development, implementation, and effects of an integrated web-based teaching model in a nursing ethics course. Nurse Educ Today. 2017;55:31-37. doi: 10.1016/j.nedt.2017.04.011

29. McLeod SA. Attitudes and behavior [Internet]. 2018 [cited 2019 May 12]. Available from: https://www.simplypsychology.org/ simplypsychology.org-Attitudes.pdf

30. Berger ZD, Boss EF, Beach MC. Communication behaviors and patient autonomy in hospital care: a qualitative study. Patient Educ Couns. 2017;100(8):1473-81. doi: 10.1016/j.pec.2017.03.006 